\title{
DÜNDAR ALP'IN HAYATI VE ESERLERİ ÜZERİNE
}

\author{
Yrd. Doç. Dr. Ramis KARABULUT*
}

ÖZ: Bu çalışmada yakın dönem Türk kültür ve edebiyatının unutulmaya terk edilmişş şahsiyetlerinden Dündar Alp'n kimliği ve eserleri üzerinde durulmuştur. Bir dergi yayıncısı, şair ve yazar olan Dündar Alp adına ilk olarak II. Meşrutiyet Dönemi'nin Türkçü dergilerinden Büyük Duygu ve Ekinci'de rastlanmaktadır. Yazar, aynı günlerde bir de tarihî roman (Şark'ın En Büyük Hükümdarı Timurlenk) kaleme almıştır. Cumhuriyet'in ilanı (1923)'ndan hemen sonra patlak veren Şeyh Sait İsyanı (1924-1925)'nda Dündar Alp adı -mağdur olarak- yer almaktadır. Bu isyanda şehit edilen kahraman öğretmen Mehmet Zeki Dündar Alp ile şair ve yazar Dündar Alp aynı kişiler midir? Bu husus aydınlatılmaya muhtaçtır. Bu durumda şöyle bir problem de ortaya çıkmaktadır: Dündar Alp gerçek bir ad mıdır, yoksa takma bir ad mıdır? Bu konuda da net bir bilgiye ulaşılamamıştır. Ancak tespit edilebilen Dündar Alp adıyla yayınlanmış eserlerden ve onun hakkında yazılanlardan hareketle bazı biyografik bilgilere ulaşmaya çalışılmıştır. Ayrıca bu çalışma hazırlanırken bazı araştırmalarda Dündar Alp adıyla yayınlanmış şiirlerin Ziya Gökalp'e ait olduğuna dair yanlış bilgilerin yer aldığı görülmüştür. Bütün bu hususlar göz önünde bulundurularak yazarın kimliğini ortaya çıkarmak için faydalı olacağına inandığımız- eski harfli bazı metinler yeni Türk harflerine aktarılarak çalışmanın sonuna ilave edilmiştir.

Anahtar Kelimeler: Dündar Alp, Büyük Duygu, Ekinci, Başöğretmen Mehmet Zeki Dündar Alp

\section{On the Life and Works of Dundar Alp}

ABSTRACT: In this study, the identity and works of Dündar Alp, who is one of the figures about to be forgotten of recent Turkish culture and literature, are studied. We come across the name of Dündar Alp for the first time as the founder, poet and writer of the pro-Turkish magazines of Büyük Duygu and Ekinci during the time of Constitutional Period II. We also know that he wrote a historical novel named Şark'ın En Büyük

\footnotetext{
* Ömer Halisdemir Üni. FEF, TDE Böl. Öğr. Üyesi, rkarabulut611@hotmail.com
} 
110

TÜBAR XLI / 2017-Bahar / Yrd. Doç. Dr. Ramis KARABULUT

Hükümdarı Timurlenk (Timurlenk, the Greatest Ruler of the Orient) on those days. Dündar Alp was a sufferer in Sheikh Said Rebellion (19241925), which broke out immediately after the announcement of Republic (1923). That is to say, we find the dramatic story of Teacher Mehmet Zeki Dündar Alp, who was martyred during this rebellion and are they the same person, or are they different people? This issue needs to be clarified. What is more, is Dundar Alp a real name or is it a nickname? In this regard, we have not been able to reach any clear evidence. We have tried to get some biographical information from the writings available and the writings about him. What's more some false information has been found out that the poems published by the name of Dündar Alp are actually written by Ziya Gökalp. We have also transliterated some texts from Arabic letters to the new Turkish letters and added them to the end of this work as we believe that it would be useful for revealing the identity of the poet.

Key Words: Dündar Alp, Büyük Duygu, Ekinci, Head Teacher Mehmet Zeki Dündar Alp

\section{Giriş}

Dündar Alp, II. Meşrutiyet Dönemi’nde Türk kültür ve edebiyat hayatında kısa bir süre (1913-1914) göründükten sonra gözden kaybolmuştur. Bu süre içinde yayıncı, şair ve yazar olarak varlık göstermiştir. Aynı isme daha sonra Cumhuriyetin İlanı'ndan hemen sonra patlak veren Şeyh Sait İsyanı sürecinde (1924-1925) rastlanmaktadır. Burada Dündar Alp (Başöğretmen Mehmet Zeki Dündar Alp) tarihî bir misyonla ortaya çıkmaktadır. Bu Dündar Alp'lar aynı kişi midir, ayrı kişiler midir? Henüz bu soru aydınlatılmaya muhtaçtır. Bütün bunlardan hareketle Dündar Alp'ın kimliği, basın ve yayın hayatındaki tezahürlerinin belirginleşmesi için konu şu üç başlık altında ele alındı:

\section{Yayıncı Dündar Alp}

II. Meşrutiyet yıllarında iki dergi ve bir roman yayınlamış olan Dündar Alp, bir şair ve yazar olarak çok kısa bir süre Türk basın ve edebiyat hayatında görünüp kaybolmuştur. İlk olarak bu dönemde Dündar Alp'1 bir yayıncı olarak görmekteyiz. Sanatçı II. Meşrutiyet Dönemi’nin ünlü Türkçü dergilerinden Büyük Duygu'nun üç kurucusundan biridir. Büyük Duygu, "On beş günde bir çıkar Türk risalesidir." sloganıyla 2 Mart 1329/15 Mart 1913 - 18 Kânunusani 1329/31 Ocak 1914 tarihleri arasında toplam 26 sayı çıkmıştır ${ }^{1}$.

1 Büyük Duygu dergisi hakkında ayrıntılı bilgi için Milli Kütüphane’de "1962 SB 31" numaradaki nüshaya bakılabilir. 
TÜBAR XLI / 2017-Bahar / Dündar Alp'ın Hayatı ve Eserleri Üzerine

Dündar Alp, Büyük Duygu'nun ilk üç sayısını M. Fazıl ve Ş. Uluğ ile birlikte, 4-26. sayıları ise tek başına yayınlamıştır. Buradan öğreniyoruz ki, Dündar Alp söz konusu iki arkadaşıyla yollarını ayırmıştır. Bu kanıya varmamızın nedeni ise, aynı günlerde M. Fazıl ve Ş. Uluğ'un Büyük Duygu'dan ayrild1ktan sonra 25 Nisan - 22 May1s 1329 [8 May1s - 4 Haziran 1913] arasında yani yaklaşık bir ay zarfında 3 sayı yayımlanan Türk Duygusu adında yeni bir dergi çıkarmaları ve derginin birinci sayısında şu açıklamayı yapmış olmalarıdır:

Şimdiye kadar Türklük hakkındaki meslek ve içtihadımızı "Büyük Duygu” adıyla tesis ettiğimiz risalede neşrediyorduk. Okuyucularımıza ihtar tebşir edebiliriz ki Büyük Duygu'nun 4.Sayısına kadar okudukları yazıların mabatlarını bugünden sonra Türk Duygusu'nda okuyacaklardır. Biz Türklük uğrunda bütün mevcudiyetimizle çalışacă̆ız. Okuyucularımızdan da ră̆bet ve teveccüh göreceğimizi umarız (Türk Duygusu 1329/1913: 1).

$\mathrm{Bu}$ açıklamadan anlıyoruz ki derginin diğer iki müessisi Büyük Duygu ve Dündar Alp'ten ayrılarak yeni bir Türkçü dergi çıkarma ihtiyacı duymuşlardır ${ }^{2}$.

Dündar Alp, Büyük Duygu ile aynı günlerde Ekinci adlı bir başka derginin de yazı işleri müdürlüğünü yapmıştır. Hüseyin ve Kasım isimli şahıslar, bu derginin müessisleri, Süleyman Tevfik de mesul müdürüdür. Dergi "Fen ve ziraatın faidesine çalışır." sloganıyla 11 Nisan 1329/24 Nisan 1913 tarihinden itibaren yaklaşık bir yıl içinde (son sayı 18 Nisan 1914) 15 sayı yayınlanmıştır. On beş günlük aralıklarla çıkan Ekinci ${ }^{3}$ dergisinde Dündar Alp imzalı hiçbir yazıya rastlanmamaktadır. Ancak derginin yazı işleri müdürü olmasından hareketle bu dergideki imzasız baş makalelerin Dündar Alp'a ait olma ihtimali de unutulmamalıdır.

\section{2. Şair ve Yazar Dündar Alp}

Büyük Duygu dergisindeki Dündar Alp imzalı iki adet şiir ve yazıların künyeleri şu şekildedir:

Türk Kartalı, Büyük Duygu, nr. 1, 2 Mart 1329, s. 3 (Türk milletinin Balkan Savaşı dolayısıyla içinde bulunduğu kötü durumdan duyulan ıstırabın dile getirildiği hamasî bir şiir.).

2 Büyük Duygu ve Türk Duygusu dergileri hakkında ayrıntılı bilgi için, bk. (Polat 2011: 64-65.).

3 Ekinci dergisi hakkında ayrıntılı bilgi için Milli Kütüphane'de "1956 SA 154" numarada kayıtlı nüshaya bakılabilir. 
112

TÜBAR XLI / 2017-Bahar / Yrd. Doç. Dr. Ramis KARABULUT

Yurdumuza Koşalım, Büyük Duygu, nr. 9, 20 Haziran 1329, s.136 (Türklüğü yurt savunmasına davet eden hamasî bir şiir.).

Şerefli Duygum!, Büyük Duygu, nr. 5, 25 Nisan 1329, s. 74-75 (Yurt sevgisini anlatan bir mensur şiir.).

Yine Şeref Bizim İçin!, Büyük Duygu, nr. 10-13 (özel say1), 10 Temmuz 1329, s. 223-224 (On Temmuz Hürriyet Bayramı dolayısıyla dört sayı bir arada çıkarılan özel nüshanın çıkarılış amacının vatana hizmet olduğunu açıklayan bir yazı.).

Bazı araştırmalarda ${ }^{4}$ Dündar Alp'a ait yukarıda künyesini verdiğimiz iki şiirin ve aynı zamanda Dündar Alp takma adının Ziya Gökalp'a ait olduğu bilgisi yer almıştır. Oysa Ziya Gökalp Dündar Alp takma adını kullanmamıştır ve şiirleri arasında bu metinler yoktur. Bu gibi karışıklıkları önlemek için Dündar Alp'ın Büyük Duygu'da yayınladığı iki şiirinin metinlerini buraya almakta fayda görüyoruz:

\section{TÜRK KARTALI}

İsterdim ki bütün güneş tutuşsun, Altın dağda kurultaylar kurulsun! Gözlerimde kızıl öçler süzülsün... Lâkin İlhan, Oğuz, Karahan susmuş!...

Altınordu gölge midir, rüya mı?

Şu gördüğüm Atilla mı, İlhan mı?

$\mathrm{Bu}$ inleyen Tuğrul mudur, Orhan mi?!

Baktım, eyvah!... Yurdum artık bozulmuş!...

Neden dursun damarımda kanlarım,

Neden sussun Hakanlarım, Hanlarım?!...

Kara yas $\mathrm{m} ı$ bağlamalı dağlarım?!...

Bülbül susmuş... Yaş gözleri bürümüș!

Yazık, yazık!... Bu güzel yer, bu dağlar

Neden böyle gölgelenmiş ovalar?!...

Yoksul kalmış... Harap olmuş mezarlar...

Hakanların otağları bozulmuş?!...

4 Bu konudaki karışıklıkların nedeni, Haluk Harun Duman'ın Balkanlar'a Veda - Basın ve Edebiyatta Balkan Savaşı (1912-1913) adlı çalışmasında verdiği bilgilerdir. Bu çalışmada Dündar Alp'e ait şiirler, "Dündar Alp (Ziya Gökalp)" şeklinde verilmiştir (Duman 2005: 109-110). Yine bir başka çalışmada da aynı bilgi tekrar edilmiştir (Süleymanoğlu Yenisoy 2012: 93). Bu konudaki karışıklığı önlemek için bk. Tansel 1989. 
TÜBAR XLI / 2017-Bahar / Dündar Alp'ın Hayatı ve Eserleri Üzerine

Bakın bakın! Şurda bir kuş... Kanadı

Kırık... Sordum bu kuşun nedir adı?

- Türk kartalı!...

Yaralarım kanad1...

Söyleyiniz, bu kanadı kim kırmış!?...

Söyleyiniz, şanlı yurdum nerede?

Söyleyiniz, Türk canları nerede?

Nerde Turan, Karakurum nerede?

Türkistan'ı moskoflar mı bürümüş!?...

Dündar Alp

(Büyük Duygu, nr. 1, 2 Mart 1329, s. 3)

YURDUMUZA KOŞALIM...

Çalışalım, vatandaşlar, arslan hisli kalbimiz, İnci kalpli sinemizde yurdumuzu saralım...

Din aşkına, hak aşkına, koşalım, kurtaralım;

Düşmanlardan bu vatanı, el bir edip şimdi biz...

Hak aşkına, din aşkına, koşalım,

Yurt uğruna karlı dağlar aşalım...

Kucak açmış, bak annemiz, yavrucağım gel diyor,

Dişlerimiz; düşmanları parçalasın, mahvetsin...

İşte vatan, işte millet, işte sancak, işte din,

Çalışmazsak; elimizden ilelebet, gidiyor...

İşte Kur'an, işte aylı bayraklar,

Öldürelim kan boyansın topraklar...

Kanlı Garb'ın kanlı yüzü anamıza göz dikmiş,

Karşıdaki homurdayan düşmanın,

Hain gözü, her dakika firsatını bekliyor...

Hiçbirimiz bakmıyoruz vatanın;

Feryadına, koşmuyoruz, bu ne iş?...

Uğraşmazsak, bir büyük dert, başımıza geliyor,

Sinemizi delecek;

Gözümüzü dört açalım, pek fenadır, bu düşmek...

Gayret, gayret vatandaşlar, çok acıdır nedamet,

Son günümüz gelmiştir.

Sükûtumuz müthiştir...

Çalışırsak; kurtuluruz, çalışmazsak: Felaket...

Karlı dağlar aşalım,

Yurdumuza koşalım...

(Büyük Duygu, nr. 9, 20 Haziran 1329, s. 136) 
114

TÜBAR XLI / 2017-Bahar / Yrd. Doç. Dr. Ramis KARABULUT

Dündar Alp'ın yazarlığı Büyük Duygu dergisindeki faaliyetleriyle sınırlı kalmamıştır. Yazar, 1914 yılında "Şark'ın Büyük Hükümdarı Timurlenk adıyla bir de roman yayınlamıştır. Romanın adının altında şu açıklama yer almaktadır: Hayat-ı Hususiye ve Siyasiyesini Musavvir Tarihî Roman". Dündar Alp, toplam 223 sayfadan ibaret olan romanının girişine "Muhterem Türklüğe -Birkaç Söz-" başlıklı bir sunuş yazısı ilave etmiştir. Bu yazıda romanı niçin yazdığını açıladıktan sonra okuyuculara eserini şöyle takdim etmektedir:

Romanımızı takip edecek kari'in Timurlenk'in makes-i hayatı olan vakayii görmekte büyük bir lezzet hissedeceklerinden emin olabiliriz. Elimizden geldiği kadar hakayık-ı tarihiyenin inkişafina çalışacak ve kari'imizin mucib-i memnuniyeti olmaya uğraşacağız! 18 Ağustos 328, Klztaşı, Dündar Alp (Dündar Alp 1330 / 1914: $10)$.

Yazar romanının sonundaki "İhtar" başlığı altında birinci cildin bittiğini bunu takip edecek ikinci cildin ise "Yıldırım Bayezid ve Timurlenk" adını taşıyacağını ve bu ciltte daha çok Ankara vakası üzerinde duracağını okuyucuya haber vermektedir. (Dündar Alp 1914: 254). Buradan da anlaşılacağı gibi yazar romanın ikinci cildini yazacağını belirtmektedir. Fakat yapılan ön araştırmada eserin devamı olan bu ikinci cilde ulaşılamamıştır. Büyük ihtimalle yazar, eserinin ikinci cildini herhangi bir sebeple yazamamış olmalıdır ${ }^{5}$.

Dündar Alp imzasına bir yerde daha rastlanmaktadır. Yazar, Tiyatro ve Temaşa Mecmuası'na tiyatro hakkındaki görüşlerini ifade eden şu kısa yazıyı göndermiştir:

Ne kadar yazıktır ki temaşa sanâyi-i nefisenin, edebiyatın en zinde, en feyyaz, en metin bir kısmı olduğu hâlde kiymet-i manzumesini takdir edemiyoruz. Teessüf olunur ki memleketimizde bu san'ata sülûk eden biç̧are vatandaşlarımı hiçbir taraftan muavenet göremeyerek bir hayat-l sefalet içinde boğulmakta, mehîp bir

5 Dündar Alp'ın bu romanı Evreca Publishing yayınevi tarafindan yeni harflere aktarılarak 2005 yılında yayınlanmıştır. Bu baskıda romanı yeni harflere aktaran belirtilmemiş ve adı da "Şarkın Büyük Hakanı Timurlenk" şeklinde eksik ve yanlış olarak aktarılmıştır. Yine bu baskıda giriş kısmındaki "18 Ağustos 1328" Rumî tarihi yanlış olarak Miladî tarihe "1909” şeklinde yanlış çevrilmiştir. Ayrıca romanın birinci paragrafındaki "1325 Sene-i Miladiyesi" tarihi de her nasılsa "31 Ağustos 1912” şeklinde tekrar Miladî tarihe çevrilmiş. Buradan anlaşılıyor ki romanın yeni harflere aktarıldığ baskıda önemli aktarma hataları vardir. 
TÜBAR XLI / 2017-Bahar / Dündar Alp'ın Hayatı ve Eserleri Üzerine

uçurumun ka'r-ı felâketine doğru sürüklenmektedirler. Cehâlet! Biz ne zaman cehâletten kurtulacak biraz tenevvür edecek olursak o zaman bizde de san'at-ı temaşa terakkî eder. Yoksa, bizde cehâlet bakî kaldlkça terakkî değil, tedennî edeceğimizden şüphe yoktur (Dündar Alp 1329/1913: 6).

\section{3. Şehit Öğretmen Dündar Alp}

Yukarıda da görüldüğü gibi 1913-1915 yılları arasında basın hayatı içinde olan Dündar Alp adına 1925 yılına kadar rastlanmamaktadır. Bu hususta yapılan araştırmalar sonucunda, Yakup Kadri Karaosmanoğlu'nun Hâkimiyet-i Milliye gazetesine yazdığ 1 bir makalede, Dündar Alp takma adını kullanan bir şehit öğretmenin hazin öyküsü ile karşılaşıldı. Bu yazıda Dündar Alp adlı öğretmenin Şeyh Sait İsyanı sırasında şehit edildiği ve bu hadisenin nasıl meydana geldiğine dair verdiği bilgilere ulaşıld. Yakup Kadri bu bilgiyi, Vakit Gazetesi Diyarbakır muhabiri Naşit Hakkı'nın Vakit gazetesine gönderdiği konu ile ilgili bir habere dayandırmaktadır. Yakup Kadri, Öğretmen Dündar Alp'ın başına gelenleri ve şehit edilmesi hadisesini şöyle özetlemektedir:

Makaleme bir hikâye ile başlayacağım. Şeyh Sait isyanı baş göstermezden birkaç ay evvel "Genç"te Dündar Alp namında genç bir mektep muallimi varmış. Bu genç muallim bir gün hiç şüphesiz müstear ad olan isminin delalet ettiği vechile ateşîn bir Türk milliyetperveri imiş. Öteden beri, birtakım mağşus ve merdud cerayanlara saha olan muhitinde, rüzgârdan hile sezen zeybek gibi, daima müteyakkız ve endişe-nâk bulunurmuş. Bu teyakkuz ve endişe sayesindedir ki, günün birinde, üç ay sonra patlak veren menfur yanglnın kokusunu duymuş. Bu hissini müteaddid telgraflarla, mektuplarla, müracaatlarla hükumete bildirmek istemiş; hatta derdini anlatabilmek için devletin en büyük bir makamına da başvurmaktan çekinmemiş. Gerçi bu büyük makam hükumet-i merkeziye vasitasıyla hükumet-i mahalliyeyi ikaz için lazım gelen emirleri vermiş, mektep mualliminin "maruzatı" üzerine valinin nazar-ı dikkatini celbe çallşmış ve vali de derhal harekete gelmiştir; fakat zavallı Dündar Alp aleyhine... Evet, Genç vilayetinin bütün hükumet cihazları harekete gelmiştir, fakat zavallı Dündar Alp aleyhine... Ve bunun neticesinde Dündar Alp, o şeyda Türk milliyetperveri bir müfteri ve müzevvir sıfattyla maznun olarak mahkemeye sevk edilmiş; hakkında hüküm verilmiş ve bilmem kaç ay hapse mahkûm olmuştur! Bu tarihten sonra Dündar Alp'ı gözden kaybediyoruz. Fakat vaktaki, Şeyh Sait avanesi "Lice"yi baslyorlar ve etrafi kana, 
116

TÜBAR XLI / 2017-Bahar / Yrd. Doç. Dr. Ramis KARABULUT

ateşe bulamaya başliyorlar, bir mektep binasının önünde Dündar Alp'ın parçalanmış cesedini buluyorlar (Karaosmanoğlu 1925: 1).

Buradan anlaşıllyor ki vatansever öğretmen, isyanı önceden haber verdiği için büyük haksızlıklara uğramış ve sonunda hunharca şehit edilmiştir. Yakup Kadri, ayrıca Dündar Alp adının bir müstear ad olduğuna da kesin gözüyle bakmaktadır. Yakup Kadri, aynı yazıda konu ile ilgili geniş bilgi için Vakit gazetesi Diyarbakır muhabiri Naşit Hakkı (Uluğ) ${ }^{6}$ 'un Dündar Alp'ın şehit edilmesi ile ilgili Vakit gazetesinde yayınlanan mektubuna müracaat edilmesini önermektedir (Uluğ 1925: 2).

Burada bahsedilen haber metninde Başöğretmen Mehmet Zeki Dündar Alp'ın Şeyh Sait Ísyanı'ndan birkaç ay önce isyan hazırlıkları ile ilgili bir tutanak tuttuğu ve daha sonra Mustafa Kemal Atatürk'e hitaben hainlerin isyan hazırlıklarını haber veren üç adet telgraf metni verdikten ve sonra da Dündar Alp'ın iftiracı konumuna düşürülerek hakkında soruşturma açıldığını, ardından da mahkemeye verilerek para cezasına çarptırıldığını ortaya koyan mahkeme tutanağı bu haber metninde yer almaktadır. Bu hususta yakın dönem Türk tarihi açısından bir belge olabileceği düşünülerek Yakup Kadri'nin ve Naşit Hakkı'nın yazıları yeni harflere aktarılarak bu yazının sonunda verilmiştir.

Naşit Hakkı'nın yer verdiği Başöğretmen Dündar Alp'ın Atatürk'e yazdığı üçüncü telgrafın üslubu ve kullanılan ifadeler Atatürk'le tanıştığını ve zaman zaman haberleştiklerini açıkça göstermektedir:

Cereyan ve mesail-i mühimme-i Kürdiyeyi himaye tarikiyle bilhassa Hacı Mehmed'i ihbar eylediğime rağmen sükût ve tebdil-i ifade eylemekliğim için "Genç" Valisi İsmail Hakkı Bey tarafindan işkence-i tehdid ve tazyika başlanıldım. İstirahatlerinin temini için memuriyetime hâtime çektiler. Değil memuriyetim zat-l halâskârîleri gibi dehâet-i vatan ve mukaddes Cumhuriyetimiz uğruna canım ve efrad-ı ailemi fedaya müheyyayım. Ifademin Hükumet-i Cumhuriye'nin makarr olan Ankara Vilâyeti merkezinde ahzına irade buyurulmasinı sabırsizlıkla beklerim efendim (Uluğ 1925: 2).

$\mathrm{Bu}$ cümlelerdeki samimiyet ve yakınlık, şehit öğretmenin sıradan bir memur olmadığı kanaatini de uyandırmaktadır.

6 Naşit Hakkı Uluğ (İstanbul 1902-1977), gazeteci ve yazar. Hakkında ayrıntılı bilgi için bk. Türk Dili ve Edebiyatı Ansiklopedisi 1998: C. 8 / 457. 
TÜBAR XLI / 2017-Bahar / Dündar Alp'ın Hayatı ve Eserleri Üzerine

Dündar Alp'ın hazin öyküsünün bazı ayrıntılarına Uğur Mumcu'nun Şeyh Sait İsyanı hakkındaki Kürt-İslâm Ayaklanması 1919-1925 (1991) adlı eserinde de yer verilmiştir. Uğur Mumcu'nun bazı anı ve İstiklâl Mahkemesi tutanaklarından hareketle verdiği bilgilerden anlaşıldığına göre Başöğretmen Mehmet Zeki Dündar Alp "Liceli Yusuf-1 Perişan Oğlu Mustafa tarafindan" sokakta vurularak öldürülmüştür. Bu cinayetten dolayı adı geçen isyanın sonrasında "Elazığ'ın Mustafapaşa Mahallesi"nden Kamberoğlu, Zeki Dündar Alp hakkında iftira ediyor bahanesiyle soruşturma açan ve gereken önlemleri zamanında almayan Genç Valisi İsmail Hakkı Bey bir yıl hapis cezasına çarptırılmış, Çapakçur Kaymakamı Hüseyin Hilmi'nin de sınır dışına çıkarılmasına karar verilmiştir (Mumcu 1991: 205). Yani ihmali görülen devlet görevlileri isyan sonrasında kurulan mahkemece cezalandırılmışlardır.

Bütün bu bilgilerden Başöğretmen Mehmet Zeki Dündar Alp'ın s1radan biri olmadığı, isyan bölgesinde oldukça etkili biri olduğu, isyancılara karşı devletin yanında yer alacak kadar da cesarete ve güce sahip olduğu sonucu çıkarılabilir. Bu bakımdan yakın dönem siyasî tarihi ile ilgi çalışmalarda ve istihbarat raporlarında hakkında aydınlatıcı bilgilere ulaşılabileceği de unutulmamalıdır.

Son olarak şehit öğretmen Dündar Alp adının ironik de olsa bir romana yansıdığından da söz edilmelidir. Şöyle ki; Cumhuriyet Dönemi romancılarından Adalet Ağaoğlu'nun Ölmeye Yatmak (2015) romanındaki idealist Dündar öğretmen tipi yukarıda bahsedilen öğretmenin başına gelenlerden dolayı $\mathrm{m} ı$ romanda yer almıştır? Bilinmez. Belki de yazar bu tipi yukarıda bahsedilen öğretmenle ilgili haberlerin etkisiyle romanına almıştır. Bu romandaki Dündar öğretmen öğrencilerine Cumhuriyet Marşl, Onuncu Yıl Marşı ve Ergenekon Destanı gibi metinleri ezberlettirecek kadar idealist, Cumhuriyetçi, inkılapçı ve resmî kurallara sıkı sıkıya bağlı olması bakımından ironik bir tarzda eleştiriye tabi tutulan bir öğretmen tipidir. Bu açıdan bakıldığında Cumhuriyet Dönemi'nin ilk şehit öğretmenlerinden Dündar Alp'ın dramatik öyküsü Ağaoğlu'na Dündar öğretmen tipini ilham etmiş olma ihtimalini de düşündürmektedir?

\section{Sonuc}

Buraya kadar Dündar Alp'ın gerçek kimliği ve eserleri hakkında elde edilen bilgiler ortaya konulmuştur. Bu bilgiler, onun bir şair, yazar

7 Ölmeye Yatmak romanının idealist öğretmeni Dündar hakkında ayrıntılı bir inceleme için bk. Büşra Sürgit, Adalet Ağaoğlu'nun Ölmeye Yatmak Adlı Romanında Eğitsel Sorunlar ve Öğretmen İmgesi, FSM İlmî Araştırmalar İnsan ve Toplum Bilimleri Dergisi, S. 4, Güz 2014, s. 141 - 156. 
118

TÜBAR XLI / 2017-Bahar / Yrd. Doç. Dr. Ramis KARABULUT

ve yayıncı olduğunu açıkça göstermektedir. Bunun yanı sıra aynı kişi olup olmadığ 1 tam olarak tespit edilemeyen Öğretmen Mehmet Zeki Dündar Alp hakkında ulaşılan bilgilere de yer verildi. Ayrıca bu konuda gazetelerde çıkmış belge niteliğindeki iki yazı da çalışmanın sonuna eklendi.

Sonuçta ulaşılan bazı ihtimaller de şöyle sıralanabilir. II. Meşrutiyet Dönemi'nde (1908 - 1923) iki adet dergi çıkarmış; yazılar, şiirler ve bir roman yayımlamış olan Dündar Alp ile Şehit Öğretmen Mehmet Zeki Dündar Alp'ın aynı kişiler olup olmadığı aydınlatılmaya muhtaçtır. Şöyle ki; şair ve yazar Dündar Alp, İstanbul basın hayatından çekildikten sonra (1915) doğu vilayetlerinden birine (Çapakçur / Bingöl) öğretmenliğe gitmiş olabilir mi? Öyle ise bu kişilerin aynı kişi olma ihtimali yüksektir. Bir başka ihtimal de şudur: Dündar Alp adı, dönemin Türkçülük akımının etkisiyle yaygınlaşmış tarihî Türk adlarından biri olarak farklı kişiler tarafından da kullanılmış olabilir. Her iki ihtimalde de yakın dönem Türk kültür ve edebiyat hayatında şair, yazar, yayıncı, öğretmen olan Dündar Alp / Dündar Alp 'lar vardır ve gerçek kimlik ve biyografisi / biyografileri aydınlatılmaya muhtaçtır. Bu maksatla ulaşılan belgeleri, bilgi eksikliklerinin giderilmesi yolunda yeni araştırmacıların dikkatine ve bilim dünyasının takdirine sunulmuştur.

\section{KAYNAKÇA}

AĞAOĞLU, Adalet (2015), Ölmeye Yatmak, Everest Yay., 2. Baskı, İstanbul.

Büyük Duygu (Dergisi) (1329/1913 - 1330/1914), Sayı: 1 - 26, Cemiyet Kütüphanesi, İstanbul.

DUMAN, Halûk Harun (2005), Balkanlara Veda - Basin ve Edebiyatta Balkan Savaşı (1912 - 1913), DUYAP Yayıncılık, İstanbul.

Dündar Alp (1329 / 1913), “Şerefli Duygum!”, Büyük Duygu, S. 5, 25 Nisan 1329, s. 74-75.

(1329 / 1913), “Türk Kartalı”, Büyük Duygu, S. 1, 2 Mart 1329, s. 3.

(1329 / 1913), "Yine Şeref Bizim İçin!”, Büyük Duygu, S. 10-13 (özel say1), 10 Temmuz 1329, s. 223-224.

(1329 / 1913), "Yurdumuza Koşalım", Büyük Duygu, S. 9, 20 Haziran 1329 , s.136.

(1330/1914), Şark'ın En Büyük Hükümdarı Timurlenk, Cemiyet Kütüphanesi, İstanbul. 
TÜBAR XLI / 2017-Bahar / Dündar Alp'ın Hayatı ve Eserleri Üzerine (2005), Şarkın Büyük Hakanı Timurlenk, Evraca Publishing Yay., İstanbul.

Ekinci (Dergisi) (1329/1913), Say1: 1 - 5, Cemiyet Kütüphanesi, İstanbul.

KARAOSMANOĞLU, Yakup Kadri (1925), "Meselenin Öbür Safhası", Hâkimiyet-i Milliye (Gazetesi), Say1: 1432, 24 Mayıs 1925, s. 1.

MUMCU, Uğur (1991), Kürt-İslâm Ayaklanması 1919 - 1925, Tekin Yayınevi, İstanbul.

POLAT, Nâzım H. (2011), “II. Meşrutiyet Devrinde Türkçü Yayın Organları”, Türk Yurdu, Cilt 31, Sayı 284, s. 52 - 82, Nisan.

SÜLEYMANOĞLU YENISOY, Hayriye, (2012), 1912 - 1913 "Balkan Savaşları'nın Edebiyata Yansıması”, Trakya Üniversitesi Balkan Araştırma Enstitüsü Dergisi, Cilt 1, Sayı 1, s. 91 - 111, Aralık.

SÜRGIT, Büşra (2014), “Adalet Ağaoğlu’nun Ölmeye Yatmak Adlı Romanında Eğitsel Sorunlar ve Öğretmen İmgesi”, FSM İlmî Araştırmalar İnsan ve Toplum Bilimleri Dergisi, S. 4, Güz 2014, s. 141 - 156.

TANSEL, Fevziye Abdullah (1989), Ziya Gökalp Külliyatı -I- Şiirler ve Halk Masallarl, Türk Tarih Kurumu Basımevi, Ankara.

Türk Dili ve Edebiyatı Ansiklopedisi (1998), Uluğ Maddesi, C. 8, Dergâh Yay., İstanbul.

Türk Duygusu (Dergisi) (1329/1913), Say1: 1 - 7, Zaman Kütüphanesi, İstanbul.

[ULUĞ], Naşit Hakkı (1341/1925), “Çapakçur Telgrafhanesi'nde Boğulan Esrar”, Vakit (Gazetesi), S. 2652, 17 Mayıs 1341/1925, s. 2.

\section{Belgeler / Metinler}

\section{MESELENIN ÖBÜR SAFHASI}

Makaleme bir hikâye ile başlayacağım. Şeyh Sait isyanı baş göstermezden birkaç ay evvel "Genç"te Dündar Alp namında genç bir mektep muallimi varmış. Bu genç muallim bir gün hiç şüphesiz müstear ad olan isminin delalet ettiği vechile ateşîn bir Türk milliyetperveri imiş. Öteden beri, birtakım mağşuş ve merdud cerayanlara saha olan muhitinde, rüzgârdan hile sezen zeybek gibi, daima müteyakkız ve endişe-nâk bulunurmuş. Bu teyakkuz ve endişe sayesindedir ki, günün birinde, üç ay sonra patlak veren menfur yangının kokusunu duymuş. $\mathrm{Bu}$ hissini müteaddid telgraflarla, mektuplarla, müracaatlarla hükumete bildirmek istemiş; hatta derdini anlatabilmek için devletin en büyük bir makamına da başvurmaktan çekinmemiş. Gerçi bu büyük makam hükumet-i merkeziye vasıtasıyla hükumet-i mahalliyeyi ikaz için lazım gelen emirleri vermiş, mektep mual- 
liminin "maruzatı" üzerine valinin nazar-1 dikkatini celbe çalışmış ve vali de derhal harekete gelmiştir; fakat zavallı Dündar Alp aleyhine... Evet, Genç vilayetinin bütün hükumet cihazları harekete gelmiştir, fakat zavallı Dündar Alp aleyhine... Ve bunun neticesinde Dündar Alp, o şeyda Türk milliyetperveri bir müfteri ve müzevvir sıfatıyla maznun olarak mahkemeye sevk edilmiş; hakkında hüküm verilmiş ve bilmem kaç ay hapse mahkûm olmuştur! Bu tarihten sonra Dündar Alp'ı gözden kaybediyoruz. Fakat vaktaki, Şeyh Sait avanesi "Lice"yi basıyorlar ve etrafı kana, ateşe bulamaya başlıyorlar, bir mektep binasının önünde Dündar Alp'ın parçalanmış cesedini buluyorlar.

Hikâye hazindir ve bunun can-hıraş teferruatına vakıf olmak isteyenler "Vakit" gazetesi Diyarbekir muhabiri Naşit Hakkı Bey'in bundan birkaç gün evvel Vakit'te intişar eden bir mektubuna müracaat edebilirler. Şimdi, biz soruyoruz, bu yavrucağın şehadetinden mesul olanlar kimlerdir? Yalnız Şeyh Sait ve avanesi mi, yoksa aynı zamanda "Genç" Valisi ve "Genç" adliyesi mi? Diyarbekir istiklal mahkemesi şayan-1 tebcil bir cezm ve imanla birincilerin cezasını vermekte ber-devamdır; fakat bu elim memleket davasının tam bir adalet dairesinde halli için ikinci sınıf mesullerin de mutlaka ceza görmeleri şarttır. "Genç"te filan vali; "Lice"de filan hâkim; "Hani"de şu idare müdürü, "Çapakçur"da bu inzibat memuru ilaahirihi; gibi, devlet nüfuzunu, devlet vilayetini bila-kayd u şart temsil edecekleri yerde birtakım mahallî tahakkümlere mümaşat-1 meslek ittihaz eylemiş ne kadar devlet memuru varsa, asilerden sonra birer birer mahkeme huzurundan geçmek mecburiyetindedirler. Biraz yukarıda hülasaten naklettiğimiz facia, şark isyanı mesuliyetinden mahallî hükumet memurları hesabına ne büyük bir hisse düştüğünü, bize kâfi sarahatle, ispat eyleyen vesaikin bir cüzüdür. H1yanet ve irtica âleminin dolaştığı yerlerdeki vahşet ve harabiyet izleri üzerinde yapılacak derin bir tetkik ve tahkik seyahati, meydana kim bilir -tesadüfen haberdar olduğumuz- bu vakadan daha müthiş nice cürüm ve cinayetler çıkaracaktır. Belli başlı mücrimlerin kafası ezildikten sonra meselenin bu safhasına geçmek bizim için millî - tarihî ve adlî zarurettir. Aksi takdirde fedakâr Cumhuriyet ordusunun başardığı şu büyük iş bizim elimizde yıpranmış ve nâ-tamam bir eser haline girecek ve Kürt kıyamı denilen hailenin son perdesi de asla kapanmış olmayacaktır.

Sorarız o vâ'ız-1 kanuna ki, hazırlamakta olduğu idari 1slahat meclisini sabık "Genç" valisi "Genç" hâkimi gibi insanların eline mi verecektir? İsyan havalisine mahsus yeni ve cezri idare sistemini bu neviden memurlar mı tatbik edecektir? Eğer böyleyse, Şarkî vilayetlerdeki iğtişaş ve irtica hareketi bugün için bitmiş, fakat yarın için başlamış telakki olunmalıdır.

Devlet işlerinin başında bulunan aziz ve muhterem arkadaşlarımız, bizi bu bedbinane ifadatımızdan dolayı mazur görsünler; biz bunları yalnız şehit Dündar Alp'in faciasından mütehassıl bir heyecanla söylemiyoruz, bir Şeyh Sait hadisesi deyip de geçiverdiğimiz şu felaketin zavallı Türk milletine kaç milyona, kaç cana mal olduğunu ve henüz ilk adımını atmaya başlayan umran hareketini kaç sene geriye ittiğini derin bir elemle müdrik bulunmaktayız. İşte bunun içindir ki gerek cezada gerek 1slahta kati ve cezri hareketin lüzumuna kailen şimdiye kadar itti- 
haz edilen bütün tedbirlere rağmen -hiç değilse birkaç zaman için- daimi bir tehlike mihrakı olmak istidadını muhafaza eden şark havalisine yalnız fevkalade kanunlar yapmak değil fevkalade memurlarda göndermek lazımdır. Meşrutiyet devrinde, valilerden birinin maiyetine gönderilen bir mektupçuyu "mefkûresiz"dir diye azlettiğini hatırlıyorum. O zaman bu harekete gülenler meyanında ben de vardım. Fakat bugün, o valiye karşı -her kim ise, her nerede ise- istifa-yı kusur etmek ihtiyacını duyuyorum. Filhakika, birçok acı tecrübeler bize şunu ispat etmiştir ki bu milletin başına gelen belaların başlıca müsebbipleri mefkûresiz devlet adamlarıyla, mefkûresiz hükumet memurlarından maada kimse değildir. Buna rağmen idare makinesinde kullandığımız insanlarda aradığımız meziyet, hâlâ mefkûreden başka her şeydir; teşkilat-1 mülkiye ve adliyeye bir parça vukuf; idare-i maslahat usulünde bir nevi mümarese; büyük ve küçük herhangi bir hükumet memuru için, indimizde kâfi bir ehliyet vesikası hükmüne geçmektedir. Lakin yalnız isyan mıntıkasından değil, memleketin her tarafından kulaklarımızı tırmalayan sesler bize bu tarz telakkinin bir an evvel değişmesi lüzumunu ihtar ediyor.

Yakup Kadri (Karaosmanoğlu)

(Hakimiyet-i Milliye, nr. 1432, 24 May1s 1925, s. 1)

\section{Suret-i Mahsusada Diyarbakır’a Gönderdiğimiz Muharririmizin Mektupları: ÇAPAKÇUR TELGRAFHANESINDE BOĞULAN ESRAR}

(Bir Muallim, isyanı vukuundan üç ay evvel haber verdiği için bir yalanla mahkûm edildi, isyanın zuhurundan sonra ise Şeyh Said'in emriyle şehit edildi.)

\section{Suret-i mahsusada gönderdiğimiz muhabirimizden:}

Maksadım yalnız bir hikâyeden ibarettir: Hikâyem Cumhuriyetimizin birliği uğrunda Lice'nin çamurlu sokaklarında fecaat-1 cinayet eliyle hayatına veda eden fedâkâr bir ibtidaî hocasının hatıra-i vataniyesidir. İsyan vukuundan üç buçuk ay evvel Çapakçur kaymakamına ve genç valisine bildirdiği için vazifesinden kovulan, bununla iktifa edilmeyerek na-hakk bir hükümle hapse, ceza-yı nakdiyeye mahkûm olan ve nihayet asiler tarafından şehit edilen Mehmet Zeki Dündar Alp'ın aziz hatırasını yâd edeceğim:

Vatanı parçalamak, müstakil bir Kürdistan teşkil etmek için şark vilayetlerimizde hainler propagandaya başladıkları vakit en mukaddes ve mübeccel müessese-i vicdanı, dini âlet ediyorlardı. Geçen seneler Hicaz'da Kral Hüseyin, gelen hacıları kendi çeteleri vasıtasıyla soyduruyor, canlarına, mallarına tasallut ediyordu.

Cumhuriyet hükumeti dâhilde ve hariçte muhafaza-i hukukuyla mükellef olduğu tebaasının fariza-i Haccı yapmak üzere Hicaz'a gittikleri takdirde bir yabancı memlekette duçar-ı felâket olacaklarını ihtar etmişti.

Bu hayr-hâhâne ihtar hain iftiracıların elinde vatanı parçalamak için istimâl edildi. Çapakçurlu Hacı Mehmed isminde bir hain hükumet konağının 
önünde, isyan planlarının hazırlandığı meclislerde bu Hac meselesini hıyanete alet etti. Şeyh Sait de bu içtimalarda bizzat hazır bulunuyor, filvaki muzmerini pek ifşa etmiyorsa da nihayet Mehmed Zeki Dündar Alp bir gün bu ifsâdâtı bir zabıt varakası halinde tespit etmek istediği vakit zabtı imzalamamakla vaziyetini bir dereceye kadar meydana çıkarıyordu. O zaman yapılan zabıt varakasının sureti aynen şudur:

\section{Çapakçur'da Tutulan Zabit:}

Çapakçur kazasının Kadı Madrak karyesinden Hacı Mehmed'in merkez-i hükumette Maliye Dairesinde Hükumet-i Cumhuriye aleyhinde ve bilhassa Mustafa Kemal Paşa Hazretleri'nin haklarında zeban-dırazlıkta bulunduğunu mübeyyin zabit varakasidir:

Şöyle ki merkum "Ferâiz-i İlâhiyeden birisi olan Hac ki, bilumum Müslümanların Hacc'a gitmesi farzdır, hatta bizim gibi zengin olanların tekrar ziyareti lâzım iken "Kemal"e bırakıyor." gibi açık bir lisanla fikri gıcıklamak ve Kürdlük zihniyeti ile "Kemal"in bu suretle İslâmiyet'e darbe vurmak istediğini söylemiş ve hazirun birer suretle mukabelede bulunmuştur. Ezcümle Varidat Kâtibi Sıdkı Efendi tarafından Hac ferâiz-i İlâhiyeden olduğu gibi insanların kendi yanlarında Hac sevabına nail olacak hasenat ve hayırlar mevcuttur gibi mukabele edildiği zaman tüccardan Bitlisli Mahmut Çavuş, Tapu Memuru Abdülhalim, Merkez Tahsildarı Halit Efendiler, Mal Müdürü Vefik Bedri Beyler mevcut idi. Aynı günde hanesine avdetle gece saat bir buçuk raddelerinde Genç Mebus-1 Sabıkı Hamdi, Çanlı Şeyh Sait Efendilerle, Kadı Madrak Karyeli Ahmet Şemdin ve daha birçok halk huzuruyla keza Hükumet-i Cumhuriyemiz aleyhine propagandada bulunmuş ve merkez-i kasabadaki ifadelerini teyid etmiştir.

Vicdanların sada-yı zindegisi işbu malumatı zabt ve kaydeylemeye bizi sevk etmiş ve mesele-i maruzada Mebus-1 Sabık Hamdi Bey de mevcut olmakla tasdik buyurmayı fariza-i zimmet addeylemiştir. Üçüncü sabah muhaveresinde hukümetin bize lazım olmadığını, hukümet bizden ne kadar uzak olursa başımız da gaileden kurtulacağını yine Çanlı Şeyh Sait mezkûr karyeli Jandarma Seyfi, Mebus-1 Sabık Hamdi Bey huzuruyla ifade etmiştir. Merkumun hülasa-i fikri her zaman hukümet-i hazıramız aleyhinde bulunmaktan ibaret olduğunu mübeyyin zabıt varakası bittanzim imza kılındı.

Çapakçur Başmuallimi

Mehmet Zeki Dündar Alp

İşbu zabıt varakası münderecatı cerayan-ı hâle muvafik ve hakikate mukarin bulunduğunu tasdik ederiz.

Genç Mebus-1 Sabıkı Kadı Madrak Karyesinde Sakin

Hamdi

(Mecliste hazır bulunanlardan karye-i mezkûreden Jandarma Seyfi, karye-i mezkûrdan Hacı Mehmet, Madrakli Ahmet Şemsettin, Çan Şeyhlerinden Mahmut Efendizâde Şeyh Sait, zabtı imzalamamışlardır.) 
TÜBAR XLI / 2017-Bahar / Dündar Alp'ın Hayatı ve Eserleri Üzerine

\section{Reis-i Cumhura Müracaat:}

Fakat hükumet memurları genç muallimin hakikat ve sadakatine istinad eden bu sözlerini bir iftirâ-âsâ heyetinde telakki ederek müdde-i umumiliği, oranın hâkimini muallimin aleyhine tahrik ettiler. Muallim işinden çıkarıldı, mahkemeye verildi. Artık mahrekler bu muvaffakıyetlerinden büyük cesaret alarak kazaya kendi memurlarını bir tertibini bularak yerleştirmeye başladılar. Kürt isyanının tahrik sahasından çıkan faaliyeti fiilî harekâta bile başlıyordu. Mehmet Zeki Dündar Alp Reis-i Cumhur Hazretleri'ne müracaat etmeye mecbur oluyor. Vilayete Kürdistan istiklâli için isyan hazırlandığını anlatmak istiyor. Vali bu hususta kendisine güçlük gösteriyor. Hatta hayatından korkuyor. Üç telgraf yazıyor. Bunlar acaba Büyük Gazi'nin ve hükumetin eline vasıl olabilmiş midir?

Bu nokta ölen muallimin kendisiyle kapanan hatıralarını ve yağma edilerek darmadağınık olan Çapakçur telgrafhanesinin dârlarda uçuşan evrakı arasında karanlık ve kapalı kalıyor. Bu üç telgraf aynen şunlardır:

\section{Birinci Telgraf:}

Ankara'da Türkiye Cumhuriyeti Reisi

\section{Halaskârâne-i Vatan Gazi Mustafa Kemal Paşa Hazretleri'ne}

Meşhur Hacı Musa Bey Genç vilâyetine kadar gelmiş ise de tesir-i nüfuzu ve fitneliği ile Bitlis eşrafından Hacı Necmeddin hafidi Sıtkı gelerek Çapakçur başmuallimliğine muallimlik şeraitini haiz olmadığı halde bilâ-imtihan Kürtçülük kuvveti tesiriyle tayin edilmiş ve ettirilmiştir. Bu tesir ve tehdit ahengine Çapakçur kaymakamı da serfürû eylemiştir. Vali beyden sorulsun ki hüviyetini tetkik eylemediği efendi kıyafetindeki bir Kürt casusunu hangi kuvvetin tahtında muallimliğe tayin etmiştir. Vilâyetten ve Çapakçur merkezlerinden bu kabil memur kıyafetli Kürt, yerli ve hariçten eşhas-1 muzırra da gelmektedir. Acaba Çapakçur'da böyle bir kuvvet ve cemaatin mevcut olduğu hissedilmedi mi? Edilmiş ise niçin Hükumet-i Cumhuriye-i Mukaddese haberdar edilmiyor. Mir-i mumaileyh muhit alevlensin, esrar-1 hükumet keşfedilsin, eşhas-1 muzırra dağılsın, tahassun eylesin ve memleket bir ihtilâl içinde mi kalsın istiyor? Acizlerini tazyik ve ifademin niçin bu muhitte verilmesini Ankara'ya ifadeye gelmekliğimi takip ve tehire uğratıyor. Çapakçur'da vücuduyla kaim maiyet-i mevat ne suretle tekzib edilecektir? İrade buyurunuz, vaziyet günden güne kesb-i vehamet ediyor. Fazlasını hükumet-i mahalliye tedkik ve tahkik buyursun, bendeniz başka esrar ve ifadeyi huzurunuzda vermeyi sabırsılıkla bekliyorum. Telgraf parası vermeye, istikraza takatım yok. Şifrem yok. Fazlaca tazyik ve tehir edilirsem çekeceğim böyle açık telgraflarla esrar-ı mühimme efrad-ı nasda şüyû bulacaktır.

Çapakçur Başmuallim-i Sabıkı Mehmet Zeki Dündar Alp 


\section{İkinci Telgraf:}

Ankara'da Türkiye Cumhuriyeti Reisi Halâskâr-1 Vatan

Gazi Mustafa Kemal Paşa Hazretlerine

Sureti Dâhiliye Vekâletine

Kürtçülük propagandası ve esrarı hakkında hükumet-i mahalliyece ifademin ahzına irade buyurulmuştur. Bu muhitte bilhassa "Genç" vilâyeti dâhilinde hissiyat ve hayat-1 memuriyetim ve efrad-1 ailemin hayatı hemen tehlikeye ma'ruzdur. İfade vermekten tevahhuş ve hazer eylerim. Kadı Madrakli Hacı Mehmet serbesttir. Propagandası tehdidi hükumet-i hazıra aleyhindeki mefsedet, melanetler tertibi ve şahsî suikast ihzaratındadırlar. Bu hususlarda evvela hayatımızın her suretle taht-1 temine aldırılmasına muntazırız. Halet-i nez'de olanlara merhamet talep, hükumet-i milliyenin adaletine dehâlet ederim, ta'cil buyurulsun efendim.

5 Kânunusani 1341

Çapakçur Merkez Başmuallimi Mehmet Zeki Dündar Alp

\section{Üçüncü Telgraf:}

\section{Ankara'da Türkiye Reis-i Cumhuru Halâskâr-1 Vatan Gazi Mustafa Kemal Paşa Hazretlerine}

Cereyan ve mesail-i mühimme-i Kürdiyeyi himaye tarikiyle bilhassa Hacı Mehmed'i ihbar eylediğime rağmen sükût ve tebdil-i ifade eylemekliğim için "Genç" Valisi İsmail Hakkı Bey tarafindan işkence-i tehdid ve tazyika başlanıldım. İstirahatlerinin temini için memuriyetime hâtime çektiler. Değil memuriyetim zat-1 halâskârîleri gibi dehâet-i vatan ve mukaddes Cumhuriyetimiz uğruna canım ve efrad-1 ailemi fedaya müheyyayım. İfademin Hükumet-i Cumhuriye'nin makarrı olan Ankara Vilâyeti merkezinde ahzına irade buyurulmasını sabirsızlıkla beklerim efendim.

Çapakçur Başmuallimi Mehmed Zeki Dündar Alp

Zavallı muallim Çapakçur'da fazla kalmaya cesaret edemiyordu, Lice'ye geliyor. Aleyhindeki davayı Çapakçur hâkimi görüyor. Sureti aynen münderic mazbata-i hükmiye ile vatanın başına büyük bir hadise-i felâket hazırlayanları haber verdiğinden dolayı lütuf görmesi lâzım gelir iken muallim tecziye ediliyor:

\section{Muamelesi 1341-1}

\section{Fıkra-i hükmiye hulâsası:}

"İcabı bitteemmül Çapakçur kazasının Kadı Madrak karyeli Hacı Mehmed'in Hükumet-i Muazzama-i Celiliye'nin aleyhinde mefsedet ve melanetler 
tertibi ve ahaliye bu zeminlerde ilkaatta bulunduğundan bahisle hilâf-1 hakikat ihbâratta bulunduğu iddiasıyla maznun-1 aleyh Sabık Çapakçur Mekteb-i İbtidâî Başmuallimi Mehmed Efendi hakkında Çapakçur Bidayet Mahkemesi Ceza Dairesinde cereyan eden mahkeme-i giyabiye neticesinde maznun mumaileyhin köylü hayatıyla alakadar bulunması ve ot, saman gibi şeylerden dolayı Hacı Mehmed'e karşı peyda ettiği şahsî iğbirar saikasıyla merkum Hacı Mehmed aleyhinde verdiği bu yoldaki ihbaratı sırf şahsî hususattan münbais ve hilâf-1 hakikat olduğu "Genç" Valiliği ile Çapakçur kaymakamlığı taraflarından fezlekeli iki kıta tahkikat-1 istidaiye ve Çapakçur Kaymakamlığının 24 Kânunusani 1341 tarih ve 53/22 numaralı muharrerat ve maznun-1 merkumun davet-i kanuniyeye adem-i icabı ve bu babda maalkasem istima edilen şahitlerin şehadetleriyle sabit olmuş ve işbu ihbarın derkâr olan asayîş-i mahalliyeye su'-i tesiri keyfiyeti sebeb-i şiddet addiyle hareket-i vakıasına tevafuk eden Kanun-1 Ceza'nın 155'inci maddesinin ikinci zeylinde ( işbu kanunda zikr ve tasrih olunan ahvâlden ma'ada hususatta her kim ahere müteallik bir maslahat için bir muamele-i resmiyeye esas olmak üzere nefsine veya gayre bir menfaat temini veya ahere mazarrat ibka1 maksadıyla hilâf-1 hakikat olarak ihbar veya tazyik-i munzamın her nevi olarak veya şehadetle tanzim veya ita eder veyahut daire veya memuriyet-i mahsusası huzurunda bu yolda beyanat-1 kâzîbede bulunur veya böyle hilaf-1 hakikat olarak evrakı bilerek istimal eylerse bir aydan üç seneye kadar hapis olunur ve beş Osmanlı altınından yüz Osmanlı altınına kadar ceza-yı nakdî alınır. Zarar vukua gelmiş ise ayrıca tazmin ettirilir.) diye muharrer olmasına binâen zeyl-i madde-i mezkure mucibince maznûn merkum Mehmed Efendi'nin üç mah müddetle hapsine ve beş Osmanlı altını ceza-yı nakdiye mahkûmiyetine ve emr-i ahir mucibince işbu ceza-yı nakdiyenin beş misline iblağına ve ceza-yı nakdî-i mezkûru tesviye etmediği veya edemediği takdirde beher rub' lira için mukabiline birer gün ayrıca hapis edilmesine 10 zabıt, 50 i'lâm ve 40 suret tebliğ masrafları ile ceman yüz kuruş mesarif-i muhakemenin kendisinden tahsiline kabil-i itiraz ve temyiz olmak üzere 1343 senesi Recebi'nin 11'inci gününe müsadif 1341 Senesi Şehr-i Şubatı'nın beşinci Perşembe günü gıyaben karar verilerek tefhimi icra kılindi.

5 Şubat 1341

(İşbu suret aslına mutabıktır.)

10 Şubat 1341

Türkiye Cumhuriyeti Çapakçur Hâkimliği

Baş Kâtib-i Adlî

(İşbu fikra-i hükmiye sureti bilmukabele aslına mutabık olduğu tasdik kılındı.)

16 Şubat 1341

Lice Mahkeme Baş Kâtibi

Fahreddin

Şubatın onuncu günü vatanperver muallim saman ve ot alışverişi yalanıyla isyanı uydurmakla mahkûm edilirken üç gün sonra Piran'da muallimin hükûmet aleyhinde tahrikât yapıldığını haber verdiği içtimalarda hazır bulunmuş 
olan Şeyh Sait isyan bayrağını kaldırıyor. Asiler Lice'ye gelince genç muallimin Kale Mahallesi'ndeki evine gidiyorlar, kendisini aşağı indirip kapısının önünde öldürüyorlar, sokaklarda sürüklüyorlar. Melun şeyhin fetvasıyla dinsiz addedilen vatanperver ve Şeyh'ten bin defa dindar zavallı genç muallimin cesedini günlerce sokaklarda köpeklere yediriyorlar. hikâyesi.

İşte artık ebediyen hayata veda etmiş bulunan genç muallimin hatırası,

Naşit Hakkı (Uluğ)

(Vakit, nr. 2652, 17 Mayıs 1341 / 1925, s. 2) 